Check for updates

Cite this: RSC Adv., 2018, 8, 41892

Received 5th November 2018

Accepted 28th November 2018

DOI: $10.1039 / \mathrm{c} 8 \mathrm{ra09155b}$

rsc.li/rsc-advances

\section{Microwave irradiation: a green approach for the synthesis of functionalized $\mathrm{N}$-methyl-1,4- dihydropyridines $\uparrow$}

\author{
M. Musawwer Khan, (D) *a Saigal, ${ }^{a}$ Sarfaraz Khan, ${ }^{a}$ Sumbulunnisan Shareef ${ }^{a}$ \\ and Subash C. Sahoo id b
}

An eco-friendly and cost-effective, microwave-assisted green approach has been developed for the synthesis of diverse functionalized $N$-methyl-1,4-dihydropyridines (1,4-DHPs). This pseudo threecomponent reaction was carried out between two equivalents of $(E)-N$-methyl-1-(methylthio)-2nitroethenamine (NMSM) and one equivalent of aromatic aldehydes under microwave irradiation at $100{ }^{\circ} \mathrm{C}$ without catalyst and solvent. Short reaction times, avoidance of toxic solvents or expensive, metallic and corrosive catalysts and no need for column chromatographic purification are among the valuable features of the presented method. Moreover, the "greenness" of the method was evaluated within the ambits of the defined green metrics such as atom economy, carbon efficiency, E-factor, reaction mass efficiency, overall efficiency, process mass intensity and solvent intensity and the method exhibited a good to excellent score.

\section{Introduction}

The development of novel, green and sustainable synthetic procedures has received substantial attention because of the growing environmental pollution and its overwhelming effect on human life. Therefore, the design of synthetic protocols with efficient atom economy under catalyst- and solvent-free conditions based on the microwave utilizing multicomponent reaction (MCR) strategy has become a central theme in the evolution of green chemistry. ${ }^{1}$ MCRs have the ability to generate conveniently only one product from three or more components in a single synthetic operation with multiple bond formation and high atom economy. ${ }^{2}$ Over the past decade, several classes of heterocycles including natural and unnatural compounds have been successfully synthesized through MCRs. ${ }^{3}$ Owing to the simple experimental processes and one-pot procedure, the application of catalytic methods involving MCR has gained remarkable attention as it allows simple and straightforward access to novel heterocyclic libraries of small molecules. ${ }^{4}$ MCRs are now renowned and considered as an efficient tool for generating complex and diverse molecules of medicinal importance. ${ }^{5}$ They also have some inherent advantages such as

\footnotetext{
${ }^{a}$ Department of Chemistry, Aligarh Muslim University, Aligarh 202002, India. E-mail: musawwer@gmail.com

${ }^{b}$ Department of Chemistry, Center of Advanced Studies in Chemistry, Panjab University, Chandigarh-160014, India

$\dagger$ Electronic supplementary information (ESI) available. CCDC 1841358. For ESI and crystallographic data in CIF or other electronic format see DOI: 10.1039/c8ra09155b
}

high bond efficiency, convergence and step economy, short synthetic period, reduction in waste products, high selectivity as well as operational simplicity. ${ }^{6}$ On the other hand, the microwave irradiation assisted synthetic protocol has also gained importance, mainly in developing sustainable solvent- and catalyst-free alternatives to laborious reactions. Additionally, these approaches give better results in contrast to traditional synthesis in terms of waste reduction, extreme drop in reaction times, and relatively isolated pure products, thereby avoiding tedious column chromatographic purification. Hence they embody a prevailing green alternative to conventional synthesis. ${ }^{7}$

Among the nitrogen containing heterocyclic compounds, functionalized 1,4-dihydropyridines are considered as invaluable scaffolds because of their abundance in natural products ${ }^{8}$ and exhibit a variety of biological activities such as antihypertension, ${ }^{9}$ anticancer, ${ }^{10}$ antioxidant, ${ }^{11}$ antiviral, ${ }^{12}$ antitumor ${ }^{13}$ anti-inflammatory, ${ }^{14}$ analgesic ${ }^{15}$ and potential calcium channel antagonist activities. ${ }^{16}$ 1,4-Dihydropyridines (1,4DHPs), particularly 4-aryl-substituted-1,4-dihydropyridines, also possess various pharmacological activities like vasodilatory, anti-atherosclerotic, bronchodilatory, antiradical, antitumor and anti-diabetic effects. ${ }^{17}$ Extensive studies have revealed that these compounds display other therapeutic properties including HIV protease inhibition, radioprotection, neuroprotection, platelet and antiaggregatory activities etc. $^{18}$ For example, compound I was found to be an anticonvulsant while compound II exhibits antileishmanial properties. ${ }^{19}$

Recently, sugar derived 1,4-dihydropyridine III was revealed to show antitumor activity against two types of tumor cell lines, 


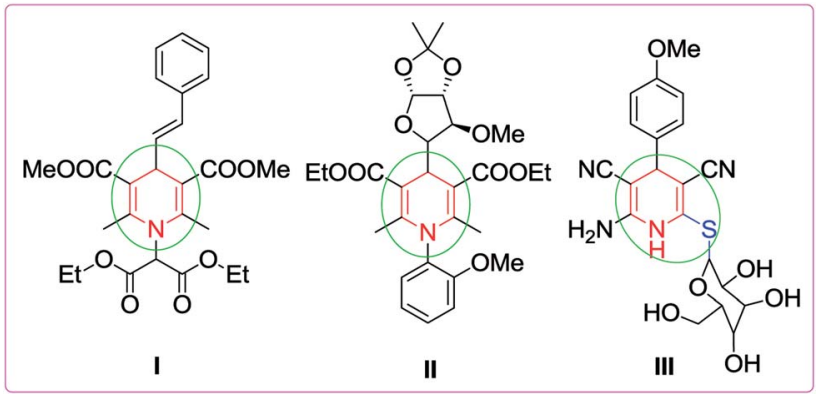

Fig. 1 Some biologically active highly substituted 1,4-DHPs.

HepG2 and HeLa (Fig. 1). ${ }^{\mathbf{2}}$ Therefore, the preparation of 1,4dihydropyridines is one of the most attractive areas of research for synthetic and medicinal chemists due to their diverse applications. For the synthesis of 1,4-DHPs, starting from the classical Hantzsch reaction, ${ }^{21}$ a number of protocols have been reported. ${ }^{22}$

In recent times, $(E)$ - $N$-methyl-1-(methylthio)-2-nitroethenamine (NMSM) has been found to be a very attractive building block for the synthesis of a variety of nitrogen and oxygen containing heterocyclic compounds. ${ }^{23}$ To the best of our knowledge, only one protocol has been reported in the literature so far for the synthesis of $N$-methyl-1,4-dihydropyridines by using NMSM and aromatic aldehydes in presence of a 2-aminopyridine catalytic system. ${ }^{24}$ However, the above method suffered from some limitations, like very long reaction time, used of toxic catalyst, used of solvent, and lower yields for some of the products. Hence, the need to develop a rapid, efficient, and environmentally benign synthetic protocol for the preparation of such 1,4-DHP derivatives is paramount and justified.

Very recently, we have reported a green approach for the synthesis of $4 \mathrm{H}$-chromen-5-ones by using NMSM, dimedone and aromatic aldehydes under catalyst- and solvent-free conditions $^{25}$ and our group also developed green protocols for the synthesis of biologically active heterocycles such as $N$ substituted-1,4-dihydropyridines, coumarin-fused 1,4-dihydropyridines, tetrahydropyridines, functionalized furan-2-one and pyrrol-2-one. ${ }^{26}$ In continuation of our research interest to develop newer synthetic methodologies under greener conditions, this paper describes an environmentally benign and sustainable method for the synthesis of highly functionalized $N$ methyl-1,4-DHPs under microwave irradiation without catalyst and solvent as depicted in Scheme 1.

\section{Results and discussion}

In our initial studies, a trial reaction was performed with benzaldehyde 1a $(1.0 \mathrm{mmol})$ and NMSM 2a $(2.0 \mathrm{mmol})$ in the presence of $10 \mathrm{~mol} \% \mathrm{ZnCl}_{2}$ under refluxing ethanol. The reaction progress and consumption of starting materials was checked by TLC. After completion of the reaction as monitored by TLC, the highly substituted $N$-methyl-1,4-DHP derivative 3a was isolated in $62 \%$ yield and the product was characterized by physical properties ${ }^{24}$ and spectroscopic techniques including IR, ${ }^{1} \mathrm{H}$ and ${ }^{13} \mathrm{C}$ NMR (Table 1 , entry 1 ). Next, we focused on an optimization study to obtain the best results in terms of yield and time. To this end, different catalysts including $\mathrm{FeCl}_{3}$, $\mathrm{SnCl}_{2} \cdot 2 \mathrm{H}_{2} \mathrm{O}, p$-toluenesulfonic acid (p-TSA), piperidine and DBU (10 mol\%) were screened in the model reaction under refluxing ethanol. Unfortunately, we did not obtain any improvement in results (Table 1, entries 2-6). Next, we attempted the same reaction in the presence of $10 \mathrm{~mol} \% \mathrm{ZnCl}_{2}$ under solvent-free conditions at $80{ }^{\circ} \mathrm{C}$ and isolated $70 \%$ yield of the product (Table 1 , entry 7 ). Similarly, we have also executed the same reaction under microwave irradiation at $80{ }^{\circ} \mathrm{C}$ without solvent in the presence of $10 \mathrm{~mol} \% \mathrm{ZnCl}_{2}$, and isolated $79 \%$ yield of the product within $20 \mathrm{~min}$. Then the same reaction was also attempted in catalyst- and solvent-free conditions under microwave irradiation at $80{ }^{\circ} \mathrm{C}$. Unexpectedly, this gave a better result in comparison with the above experiments (Table 1 , entry 9). Next, to optimize the reaction temperature of this transformation, the above model reaction was executed at different temperatures including $90{ }^{\circ} \mathrm{C}, 100{ }^{\circ} \mathrm{C}, 105^{\circ} \mathrm{C}, 110^{\circ} \mathrm{C}$ and $120^{\circ} \mathrm{C}$ under microwave irradiation excluding catalyst and solvent (Table 1, entries 10-14). From the above observations, the reaction performed without catalyst and solvent under microwave irradiation at $100{ }^{\circ} \mathrm{C}$ emerged as the optimal reaction conditions in terms of the yields and time (Table 1, entry 11). The optimization of reaction yields $v s$. the reaction temperature is depicted in Fig. 2.

After establishing the optimized conditions, we examined the reaction of NMSM with 4-nitrobenzaldehyde and obtained the desired $N$-methyl-1,4-dihydropyridine derivative $3 \mathbf{b}$ in $85 \%$ yield within $10 \mathrm{~min}$. Next, we proceeded to investigate the substrate scope for the presented method with various aromatic aldehydes having substituents including $\mathrm{NO}_{2}, \mathrm{Cl}, \mathrm{Br}, \mathrm{F}, \mathrm{OMe}$, $\mathrm{Me}$ and Et under the optimal reaction conditions, and the reaction time and yield of the isolated products $\mathbf{3 c - 3 0}$ are summarized in Table 2.

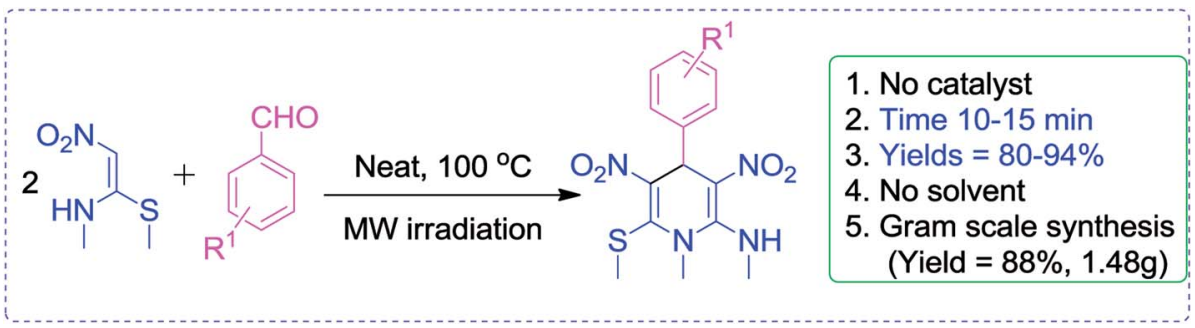

Scheme 1 Synthesis of highly functionalized $N$-methyl-1,4-dihydropyridines. 


\begin{tabular}{|c|c|c|c|c|c|}
\hline Entry & Catalyst (mol\%) & Solvent & Temp. $\left({ }^{\circ} \mathrm{C}\right)$ & Time & Yield $^{b}(\%)$ \\
\hline 1 & $\mathrm{ZnCl}_{2}(10)$ & EtOH & 80 & $5 \mathrm{~h}$ & 62 \\
\hline 2 & $\mathrm{FeCl}_{3}(10)$ & EtOH & 80 & $7 \mathrm{~h}$ & 52 \\
\hline 7 & $\mathrm{ZnCl}_{2}(10)$ & Neat & 80 & $50 \mathrm{~min}$ & 70 \\
\hline 8 & $\mathrm{ZnCl}_{2}(10)$ & Neat & $80(\mu \mathrm{w})$ & $20 \mathrm{~min}$ & 79 \\
\hline 9 & None & Neat & $80(\mu \mathrm{w})$ & $20 \mathrm{~min}$ & 82 \\
\hline 10 & None & Neat & $90(\mu \mathrm{w})$ & $15 \mathrm{~min}$ & 89 \\
\hline 11 & None & Neat & $100(\mu w)$ & $10 \mathrm{~min}$ & 94 \\
\hline 12 & None & Neat & $105(\mu \mathrm{w})$ & $10 \mathrm{~min}$ & 93 \\
\hline 13 & None & Neat & $110(\mu \mathrm{w})$ & $10 \mathrm{~min}$ & 91 \\
\hline 14 & None & Neat & $120(\mu \mathrm{w})$ & $10 \mathrm{~min}$ & 89 \\
\hline
\end{tabular}

${ }^{a}$ Reaction conditions: NMSM (1a $\left.2.0 \mathrm{mmol}\right)$, benzaldehyde $(2 \mathrm{a} 1.0 \mathrm{mmol}) .{ }^{b}$ Isolated yields. $\mu \mathrm{w}=$ microwave irradiation.

In general, the reaction proceeded smoothly under the optimized conditions to afford the desired products in good to excellent yields. It was observed that several functionalities, including both electron donating and electron withdrawing groups, in the aromatic ring were compatible with the reaction conditions.

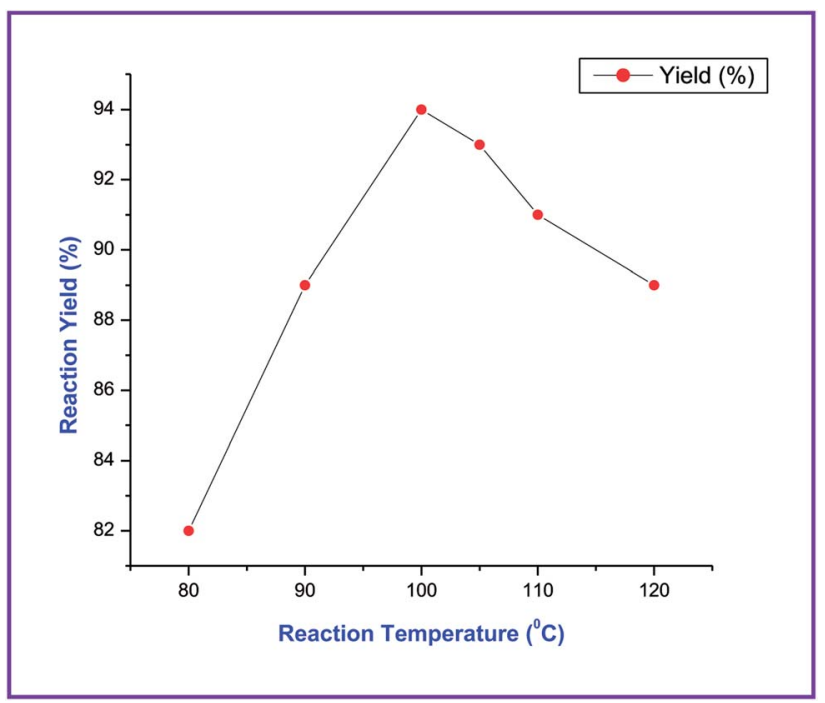

Fig. $2 \%$ yield of reaction vs. reaction temperature for the synthesis of 3a.
Furthermore, the reactions of NMSM with heteroaryl aldehydes including thiophene-2-carbaldehyde, pyridine-3carbaldehyde and indole-3-carbaldehyde were executed under this protocol and yielded the corresponding products $\mathbf{3 p}-\mathbf{3 r}$ in $80-86 \%$ yield. In addition, 2-naphthaldehyde also gave the desired product $3 \mathrm{~s}$ in $88 \%$ yield on heating with NMSM under microwave irradiation at $100{ }^{\circ} \mathrm{C}$ as shown in Table 2 . After achieving excellent results in terms of yields and time, we moved to practical testing and explored our protocol on the gram-scale level under the optimized conditions.

The gram scale preparation of 3a was carried out, wherein benzaldehyde $(5.0 \mathrm{mmol})$ successfully reacted with NMSM $(10.0$ $\mathrm{mmol})$ under the optimized conditions to yield the desired product in $88 \%$ yield $(1.48 \mathrm{~g}$ ) after $15 \mathrm{~min}$ as depicted in Scheme 1. The newly synthesized compounds were confirmed by their melting points, spectroscopic techniques (FTIR, ${ }^{1} \mathrm{H}$ NMR, ${ }^{13} \mathrm{C}$ NMR, HRMS) and elemental analysis, and matched well with the reported data. ${ }^{24}$ The spectroscopic data are in good agreement with the proposed structure and some characteristic NMR peaks assigned for compound $3 \mathbf{n}$ are shown in Fig. S2 (see ESI $\dagger$ ). Finally, the structure as well as the relative stereochemistry of 1,4-dihydropyridine $3 \mathbf{n}$ was confirmed by X-ray crystallographic analysis (CCDC 1841358). From the crystal structure, it was found that the 1,4-dihydropyridine ring adopted a boat conformation in which the flag pole positions 1 and 4 are occupied by the $-\mathrm{N}-\mathrm{CH}_{3}$ and $-\mathrm{Ph}-\mathrm{CH}_{3}$ group respectively. The ORTEP representation of compound $\mathbf{3 n}$ is presented in Fig. 3. 
Table 2 Substrate scope for the synthesis of $N$-methyl-1,4-DHPs $(3 a-s)^{a}$

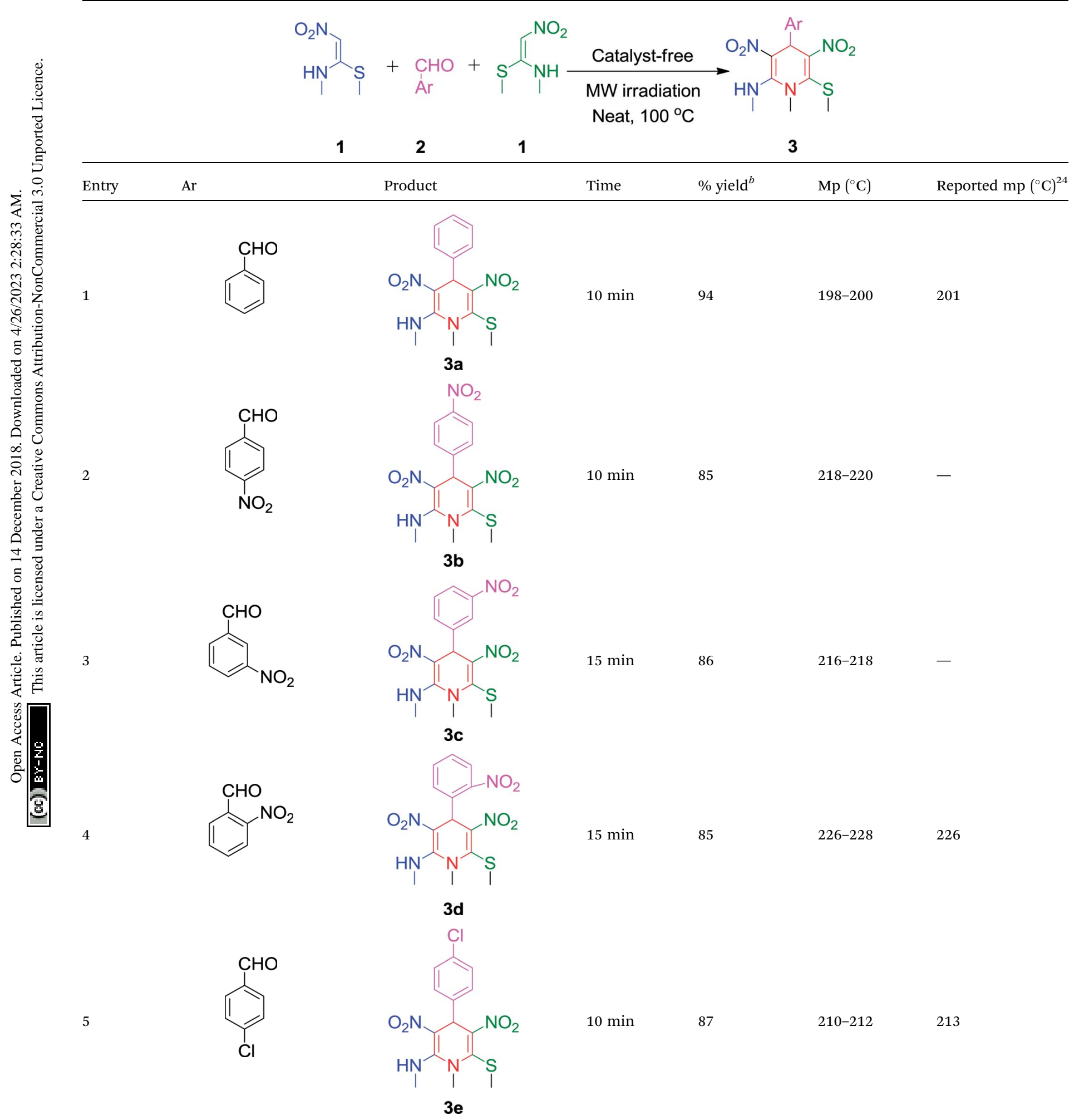


Table 2 (Contd.)

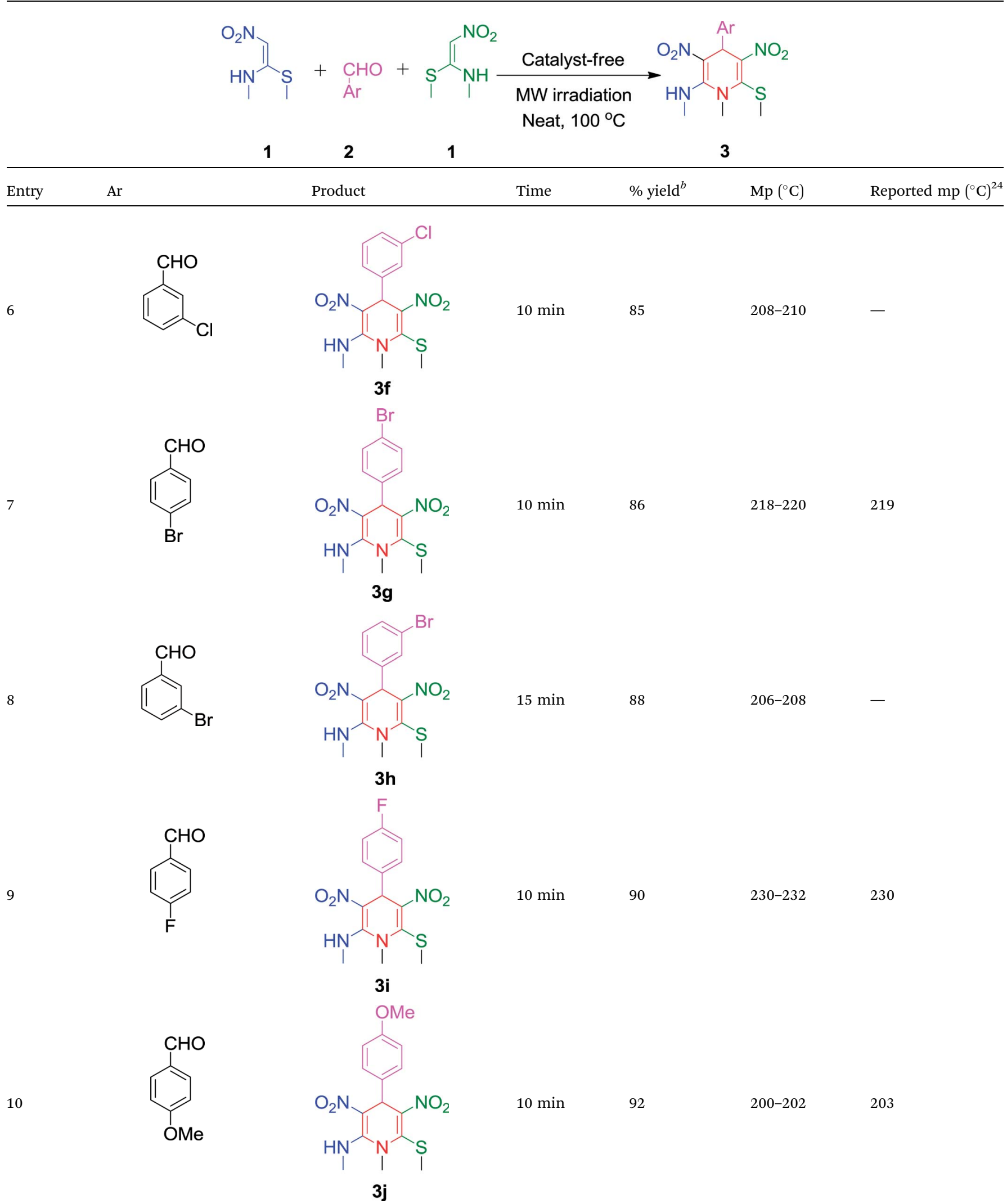


Table 2 (Contd.)

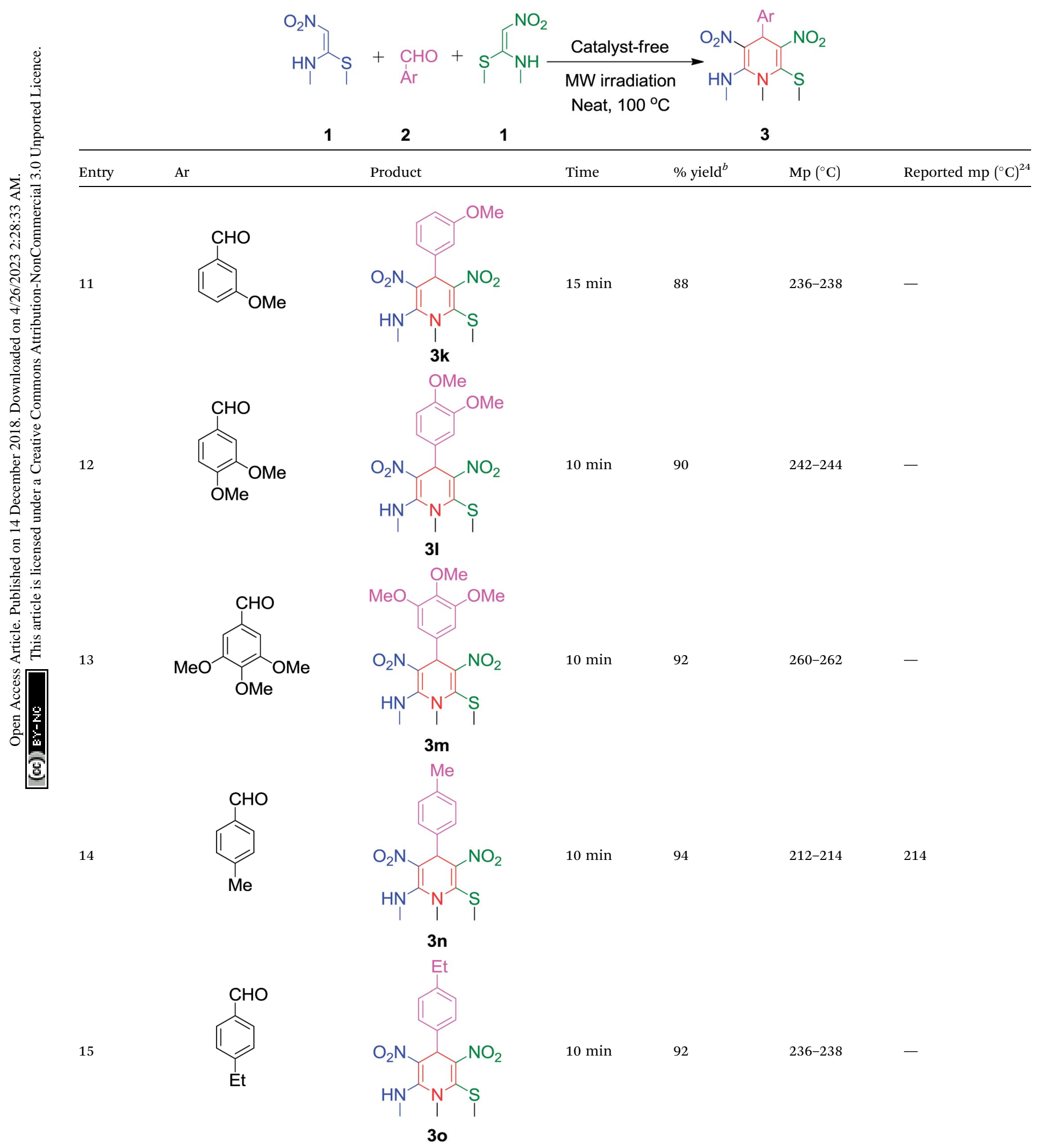


Table 2 (Contd.)

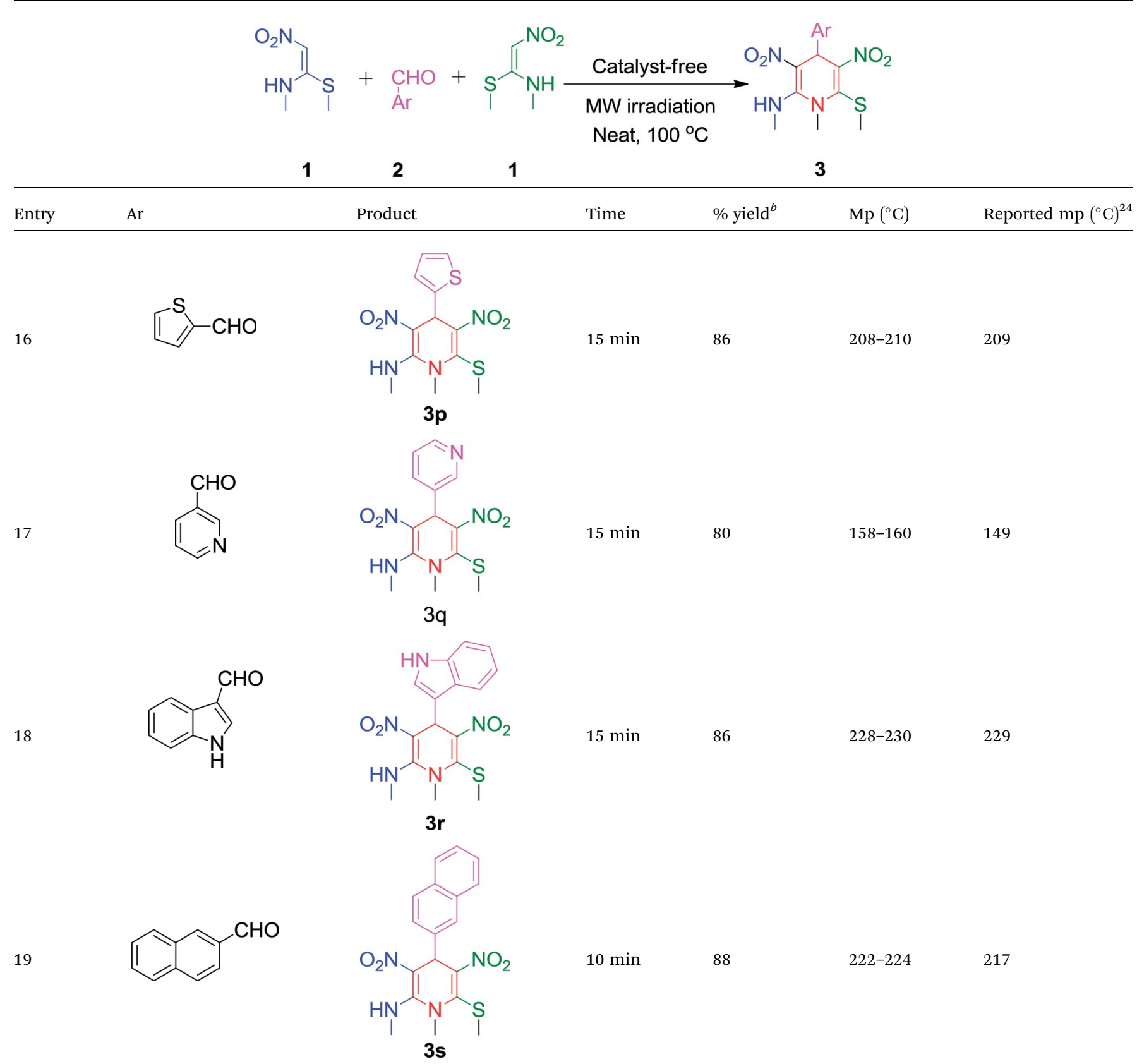

${ }^{a}$ NMSM and aromatic aldehydes in a $2: 1$ ratio, microwave irradiation $(200 \mathrm{~W})$ at $100{ }^{\circ} \mathrm{C} .{ }^{b}$ Isolated yields.

A single crystal was mounted on a glass fibre and used for data collection. A metallic light yellow coloured crystal of compound $3 \mathbf{n}$ was grown by slow evaporation of acetonitrile solvent for X-ray analysis. The single crystal X-ray diffraction data were collected from a SuperNova diffractometer, single source at offset/far, with a HyPix3000 detector using graphitemonochromated MoK $\alpha$ radiation $(\lambda=0.71073 \AA)$ at $293 \mathrm{~K}$. The crystallized compound has a triclinic crystal system, space group $P \overline{1}$, and unit cell dimensions $a=7.3596(3) \AA, b=$ 9.2464(6) $\AA, c=14.1726(5) \AA$. The unit cell packing of the compound $3 \mathrm{n}$ is shown in Fig. 4.
Finally, a plausible reaction mechanism for the synthesis of $N$-methyl-1,4-dihydropyridine was proposed, as shown in Scheme 2. We consider that the first step involves the Knoevenagel condensation of one molecule of NMSM and aromatic aldehyde to form intermediate I. To study the formation of proposed intermediate I and to isolate it, we have also conducted a reaction with NMSM $(1.0 \mathrm{mmol})$ and benzaldehyde $(1.0$ mmol) under the optimised reaction conditions, but unfortunately we unable to isolate the intermediate $\mathbf{I}$. In this control case we obtained the proposed product in lower yield. Nonetheless, we proceed on the assumption that the intermediate I 


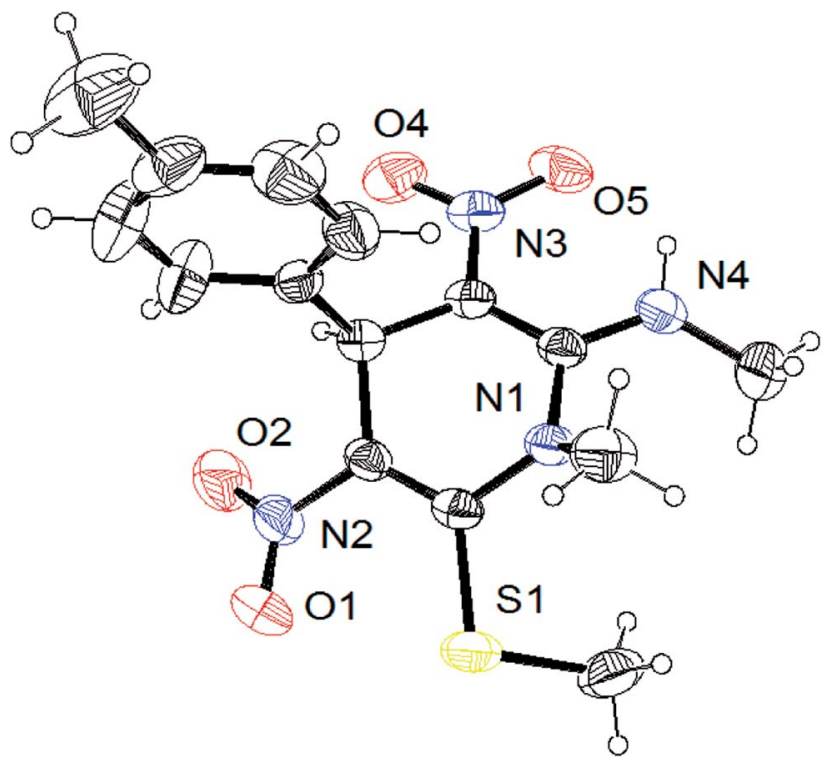

Fig. 3 ORTEP diagram of compound 3n (CCDC 1841358).

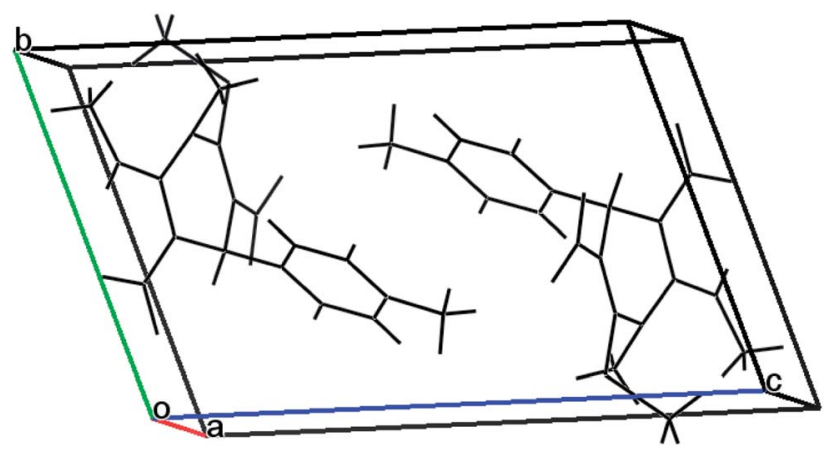

Fig. 4 Unit cell packing of compound 3n. was formed, which acted as a Michael acceptor and reacted with the Michael donor compound NMSM. ${ }^{23 b, 24}$

Another molecule of NMSM reacted with Knoevenagel product I and formed Michael adduct II, which underwent rotation to give conformer III. Then, the key intermediate III underwent intra-molecular $N$-cyclization to form species IV. Finally the species IV afforded the desired product by the elimination of $-\mathrm{MeSH}$. In contrast the elimination of $-\mathrm{MeNH}_{2}$ and formation of $3 \mathbf{a}^{\prime}$ (2,6-bismethylthio derivative) were not observed. Comparing the leaving capacity of $-\mathrm{MeNH}_{2}$ and $-\mathrm{MeSH}$, the latter is more labile and has a greater leaving tendency.

In the context of green chemistry, it was required to validate our synthetic method as environmentally benign, which was performed through the evaluation of green chemistry metrics for this one-pot synthesis of $N$-methyl-1,4-dihydropyridines. ${ }^{27-29}$ Several green metrics, including atom economy (AE), carbon efficiency (CE), reaction mass efficiency (RME), overall efficiency $(\mathrm{OE})$, process mass intensity (PMI), $E$-factor and solvent intensity (SI), have been evaluated for all the synthesized compounds, which empowers us to assess the present synthetic method in terms of waste, carbon efficiency and energy usage. The calculated values of the green metrics of all the synthesized compounds are summarized in Table S2 (see ESI $\dagger$ ).

The calculated values, including high atom economy (8386\%), carbon efficiency (93-94\%), overall efficiency (85-94\%), and small $E$-factor (4-3), solvent intensity (4-3) and PMI (5-4), endorse this presented method as green and sustainable.

\section{Conclusion}

In summary, the present study demonstrated the development of a rapid, sustainable, environmentally benign and highly efficient synthetic protocol for the preparation of $N$-methyl-1,4dihydropyridine derivatives under microwave irradiation

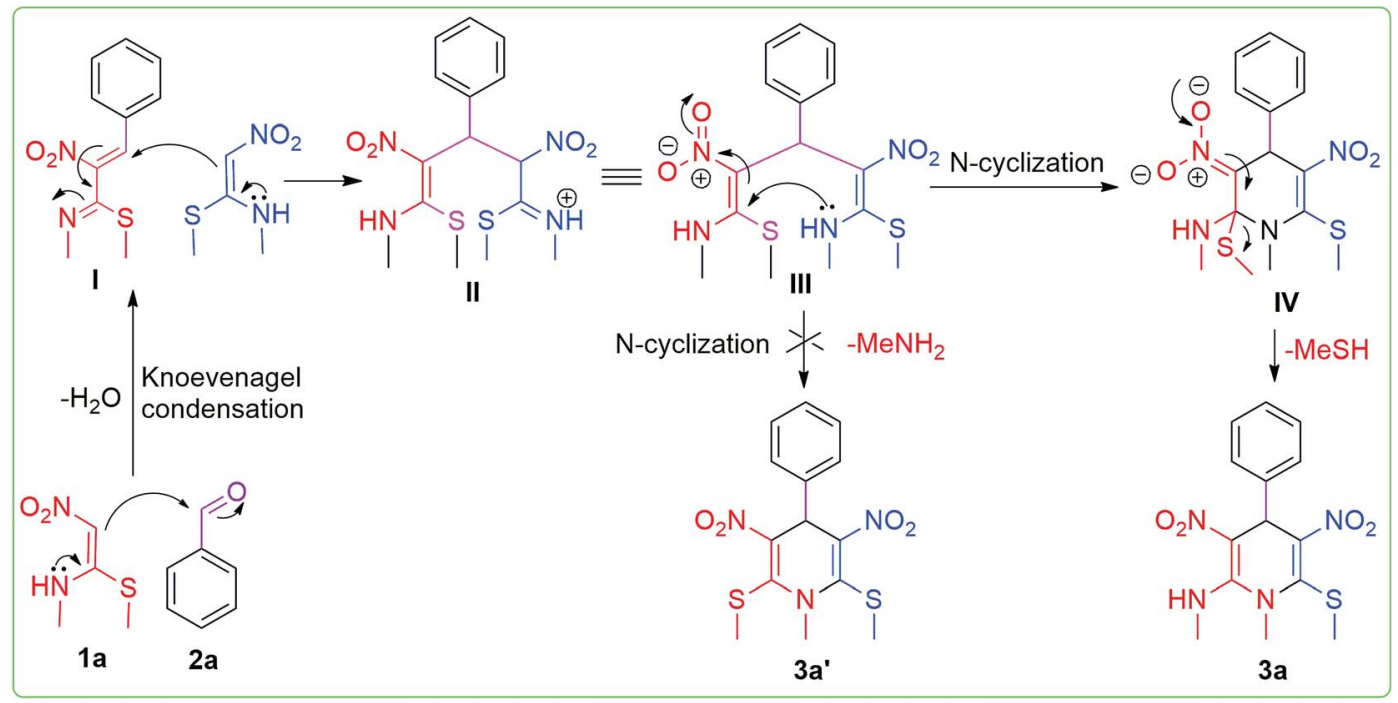

Scheme 2 Plausible reaction mechanism for the synthesis of $N$-methyl-1,4-DHPs. 
without catalyst and solvent. This protocol offers noteworthy advantages such as good to excellent yields, short reaction time, avoidance of toxic catalyst and solvent, wide range of applicability, purification by crystallization, easily available starting materials, low cost, clean reaction profiles and good amenability with the principles of green chemistry. In addition, the presented methodology produced smaller amounts of waste, with good to excellent values of green chemistry metrics (AE, CE, RME, OE, PMI, SI and $E$-factor), and our method stands as an exemplary choice in this framework.

\section{Experimental section}

\section{General information}

Commercially available solvents and chemicals were obtained from suppliers and used to execute this work as received unless otherwise mentioned. All the reactions were performed on a Monowave 300 microwave synthesizer (Anton Paar) by employing a glass vial G10. TLC analysis was performed using silica gel GF-254 from SRL. Stuart digital melting point apparatus (SMP10) was used for the measurement of melting points, which are uncorrected. FTIR spectra were recorded in potassium bromide pellets on a Perkin-Elmer 10.4.00 IR spectrophotometer. ${ }^{1} \mathrm{H}$-NMR and ${ }^{13} \mathrm{C}$-NMR spectral analysis were carried out on Bruker (Avance-II $400 \mathrm{MHz}$, Varian-AS400 NMR) spectrometers using TMS as an internal standard and DMSO- $d_{6}$ as a solvent. Crystal data were collected with a SuperNova diffractometer, single source at offset/far, with a HyPix3000 detector (CCD) at $293 \mathrm{~K}$ using graphite monochromated MoK $\alpha$ radiation $(\lambda=0.71073 \AA)$. Elemental analysis was performed on a Perkin-Elmer-2400 CHN/S analyser and Thermo Scientific (FLASH 2000) analyser while high resolution mass spectra were recorded on an ORBITRAP mass analyser (Thermo Scientific, Q Exactive) under electrospray ionisation (ESI) conditions.

\section{General procedure for the preparation of $N$-methyl-1,4- dihydropyridines (3a-s)}

A mixture of aromatic aldehydes (1.0 mmol) and (E)- $N$-methyl-1(methylthio)-2-nitroethenamine (NMSM) (2.0 mmol) was taken in a glass vial G10 and irradiated with microwave radiation (200 W) at $100{ }^{\circ} \mathrm{C}$ on a Monowave 300 synthesizer for $10-15 \mathrm{~min}$. The reaction progress and consumption of starting materials were checked by TLC. After completion of the reaction as indicated by TLC, the resulting precipitate-containing glass vial was withdrawn from the microwave oven and allowed to cool. Then the precipitate was washed with $1.5 \mathrm{~mL}$ of cold ethanol and dried. Recrystallization was performed from hot ethanol to provide the pure products.

\section{Spectral data of synthesized compounds}

$N, 1-D i m e t h y l-6-(m e t h y l t h i o)-3,5-d i n i t r o-4-p h e n y l-1,4-$ dihydropyridin-2-amine (3a). Isolated as yellow solid; yield: 94\%; 317 mg; mp: 198-200 ${ }^{\circ} \mathrm{C}$; IR ( $\left.\mathrm{KBr}, \mathrm{cm}^{-1}\right)$ : 3238, 3014, 2954, 2934, 1621, 1561, 1496, 1356, 1246, 1172, 1070, $721 \mathrm{~cm}^{-1} ;{ }^{1} \mathrm{H}$ NMR (400 MHz, DMSO- $d_{6}$ ) $\delta 2.58(\mathrm{~s}, 3 \mathrm{H}), 3.10(\mathrm{~s}, 3 \mathrm{H}), 3.46(\mathrm{~s}$, $3 \mathrm{H}), 5.99(\mathrm{~s}, 1 \mathrm{H}), 7.16(\mathrm{~d}, J=8.4 \mathrm{~Hz}, 2 \mathrm{H}), 7.23-7.28(\mathrm{~m}, 1 \mathrm{H}), 7.32$ $(\mathrm{t}, J=8 \mathrm{~Hz}, 2 \mathrm{H}), 10.12(\mathrm{~s}, 1 \mathrm{H}),{ }^{13} \mathrm{C}$ NMR (100 MHz, DMSO- $\left.d_{6}\right)$ $\delta 16.6,32.4,41.0,43.3,113.3,127.2$, 128.0, 129.4, 137.7, 140.3, 155.5, 156.5; anal. calcd (\%) for $\mathrm{C}_{14} \mathrm{H}_{16} \mathrm{~N}_{4} \mathrm{O}_{4} \mathrm{~S}: \mathrm{C}, 49.99 ; \mathrm{H}$, 4.79; N, 16.66; S, 9.53. Found: C, 49.90; H, 4.77; N, 16.62, S, 9.50.

N,1-Dimethyl-6-(methylthio)-3,5-dinitro-4-(4-nitrophenyl)-1,4dihydropyridin-2-amine (3b). Isolated as yellow solid; yield: 85\%; $325 \mathrm{mg}$; mp: $218-220{ }^{\circ} \mathrm{C}$; IR $\left(\mathrm{KBr}, \mathrm{cm}^{-1}\right): 3214,3024,2958$, 1628, 1560, 1492, 1356, 1270, 1158, 1060, $720 \mathrm{~cm}^{-1} ;{ }^{1} \mathrm{H}$ NMR $\left(400 \mathrm{MHz}, \mathrm{DMSO}-d_{6}\right) \delta 2.61(\mathrm{~s}, 3 \mathrm{H}), 3.11(\mathrm{~d}, J=4.8 \mathrm{~Hz}, 3 \mathrm{H}), 3.49$ (s, 3H), 6.09 (s, 1H), 7.45 (d, $J=8.4 \mathrm{~Hz}, 2 \mathrm{H}), 8.17$ (d, $J=8.8 \mathrm{~Hz}$, $2 \mathrm{H}), 10.13(\mathrm{~s}, 1 \mathrm{H}),{ }^{13} \mathrm{C}$ NMR (100 MHz, DMSO- $\left.d_{6}\right) \delta 16.8,32.4$, 41.1, 43.5, 112.5, 124.6, 128.8, 136.1, 147.3, 147.5, 156.4, 157.3; anal. calcd (\%) for $\mathrm{C}_{14} \mathrm{H}_{15} \mathrm{~N}_{5} \mathrm{O}_{6} \mathrm{~S}: \mathrm{C}, 44.09 ; \mathrm{H}, 3.96 ; \mathrm{N}, 18.36, \mathrm{~S}$, 8.41. Found: C, 43.96; H, 3.94; N, 18.32, S, 8.44; ESI-HRMS: anal. calcd for $\left[\mathrm{C}_{14} \mathrm{H}_{15} \mathrm{~N}_{5} \mathrm{O}_{6} \mathrm{~S}+\mathrm{H}^{+}\right]$: calcd: 382.0815 , found: 382.0816 .

$N$,1-Dimethyl-6-(methylthio)-3,5-dinitro-4-(3-nitrophenyl)-1,4dihydropyridin-2-amine (3c). Isolated as yellow solid; yield: $86 \%$; $329 \mathrm{mg}$; mp: $216-218^{\circ} \mathrm{C}$; IR (KBr, cm $\left.{ }^{-1}\right): 3226,3021,2954,1623$, 1563, 1490, 1356, 1272, 1156, 1062, $725 \mathrm{~cm}^{-1} ;{ }^{1} \mathrm{H}$ NMR (400 MHz, DMSO- $\left.d_{6}\right) \delta 2.61(\mathrm{~s}, 3 \mathrm{H}), 3.11(\mathrm{~d}, J=4.0 \mathrm{~Hz}, 3 \mathrm{H}), 3.51(\mathrm{~s}$, $3 \mathrm{H}), 6.06(\mathrm{~s}, 1 \mathrm{H}), 7.65(\mathrm{t}, J=7.6 \mathrm{~Hz}, 2 \mathrm{H}), 7.95(\mathrm{~s}, 1 \mathrm{H}), 8.12-8.15$ $(\mathrm{m}, 1 \mathrm{H}), 10.17(\mathrm{~s}, 1 \mathrm{H}),{ }^{13} \mathrm{C}$ NMR $\left(100 \mathrm{MHz}, \mathrm{DMSO}-d_{6}\right) \delta 16.8$, 32.5, 41.0, 43.7, 107.2, 122.1, 123.1, 131.1, 134.0, 136.2, 142.2, 148.4, 156.4, 157.6; anal. calcd (\%) for $\mathrm{C}_{14} \mathrm{H}_{15} \mathrm{~N}_{5} \mathrm{O}_{6} \mathrm{~S}: \mathrm{C}, 44.09 ; \mathrm{H}$, 3.96; N, 18.36, S, 8.41. Found: C, 44.18; H, 3.98; N, 18.39, S, 8.44.

4-(4-Chlorophenyl)- $N$,1-dimethyl-6-(methylthio)-3,5-dinitro1,4-dihydropyridin-2-amine (3e). Isolated as yellow solid; yield: 87\%; 323 mg; mp: 210-212 ${ }^{\circ} \mathrm{C}$; IR (KBr, $\left.\mathrm{cm}^{-1}\right)$ : 3203, 3016, 2938, 1630, 1564, 1485, 1395, 1270, 1184, 1076, $722 \mathrm{~cm}^{-1} ;{ }^{1} \mathrm{H}$ NMR (400 MHz, DMSO- $d_{6}$ ) $\delta 2.58(\mathrm{~s}, 3 \mathrm{H}), 3.09(\mathrm{~s}, 3 \mathrm{H}), 3.45(\mathrm{~s}, 3 \mathrm{H}), 5.95$ $(\mathrm{s}, 1 \mathrm{H}), 7.11(\mathrm{~d}, J=8.4 \mathrm{~Hz} 2 \mathrm{H}), 7.51$ (d, $J=8.4 \mathrm{~Hz}, 2 \mathrm{H}), 10.11$ (s, $1 \mathrm{H}),{ }^{13} \mathrm{C}$ NMR (100 MHz, DMSO- $\left.d_{6}\right) \delta 16.5,32.5,40.6,43.3$, $113.5,114.7,128.4,132.2,138.0,155.0,156.5,159.1$; anal. calcd (\%) for $\mathrm{C}_{14} \mathrm{H}_{15} \mathrm{ClN}_{4} \mathrm{O}_{4} \mathrm{~S}$ : C, 45.35; H, 4.08; N, 15.11, S, 8.65. Found: C, 45.25; H, 4.06; N, 15.07, S, 8.62.

4-(4-Methoxyphenyl)-N,1-dimethyl-6-(methylthio)-3,5-dinitro1,4-dihydropyridin-2-amine (3f). Isolated as yellow solid; yield: 85\%; $316 \mathrm{mg}$; mp: $208-210^{\circ} \mathrm{C}$; IR $\left(\mathrm{KBr}, \mathrm{cm}^{-1}\right): 3230,3025,2942$, 2834, 1632, 1560, 1489, 1350, 1282, 1170, 1072, $786 \mathrm{~cm}^{-1} ;{ }^{1} \mathrm{H}$ NMR (400 MHz, DMSO- $\left.d_{6}\right) \delta 2.59(\mathrm{~s}, 3 \mathrm{H}), 3.11(\mathrm{~d}, J=5.2 \mathrm{~Hz}, 3 \mathrm{H})$, 3.47 (s, 3H), $5.97(\mathrm{~s}, 1 \mathrm{H}), 7.09$ (d, $J=6.4 \mathrm{~Hz}, 1 \mathrm{H}), 7.17(\mathrm{~s}, 1 \mathrm{H})$, 7.07 (q, $J=7.6 \mathrm{~Hz}, 2 \mathrm{H}), 10.15(\mathrm{~s}, 1 \mathrm{H}),{ }^{13} \mathrm{C} \mathrm{NMR}(100 \mathrm{MHz}$, DMSO- $\left.d_{6}\right) \delta 16.7,32.4,40.8,43.5,112.8,125.8,127.3,128.1$, $131.4,133.8,136.8,142.6,156.4,156.6$; anal. calcd (\%) for $\mathrm{C}_{14}{ }^{-}$ $\mathrm{H}_{15} \mathrm{ClN}_{4} \mathrm{O}_{4} \mathrm{~S}: \mathrm{C}, 45.35 ; \mathrm{H}, 4.08 ; \mathrm{N}, 15.11$, S, 8.65 found: $\mathrm{C}, 45.21$; $\mathrm{H}, 4.10 ; \mathrm{N}, 15.08$; S, 8.61; anal. calcd for $\left[\mathrm{C}_{14} \mathrm{H}_{15} \mathrm{ClN}_{4} \mathrm{O}_{4} \mathrm{~S}+\mathrm{H}^{+}\right]$: calcd: 371.0575 , found: 371.0575 .

4-(4-Bromophenyl)- $N$,1-dimethyl-6-(methylthio)-3,5-dinitro1,4-dihydropyridin-2-amine (3g). Isolated as light yellow solid; yield: $86 \%$; $358 \mathrm{mg}$; mp: $218-220{ }^{\circ} \mathrm{C}$; IR $\left(\mathrm{KBr}, \mathrm{cm}^{-1}\right): 3239,3016$, 2931, 1631, 1561, 1485, 1396, 1283, 1164, 1039, $726 \mathrm{~cm}^{-1} ;{ }^{1} \mathrm{H}$ NMR (400 MHz, DMSO- $d_{6}$ ) $\delta 2.52(\mathrm{~s}, 3 \mathrm{H}), 3.19(\mathrm{~s}, 3 \mathrm{H}), 3.46(\mathrm{~s}$, $3 \mathrm{H}), 6.11(\mathrm{~s}, 1 \mathrm{H}), 6.97(\mathrm{~d}, J=6.8 \mathrm{~Hz}, 2 \mathrm{H}), 7.18(\mathrm{~d}, J=8 \mathrm{~Hz}, 2 \mathrm{H})$, $10.06(\mathrm{~s}, 1 \mathrm{H}),{ }^{13} \mathrm{C}$ NMR $\left(100 \mathrm{MHz}, \mathrm{DMSO}-d_{6}\right) \delta 16.3,31.6,40.6$, 42.7, 111.2, 115.5, 115.7, 128.5, 128.6, 142.8, 146.5, 156.0; anal. calcd (\%) for $\mathrm{C}_{14} \mathrm{H}_{15} \mathrm{BrN}_{4} \mathrm{O}_{4} \mathrm{~S}: \mathrm{C}, 40.49 ; \mathrm{H}, 3.64 ; \mathrm{N}, 13.49, \mathrm{~S}, 7.72$. Found: C, 40.40; H, 3.62; N, 13.45, S, 7.69. 


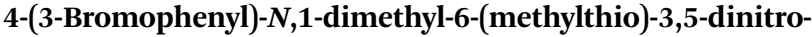
1,4-dihydropyridin-2-amine (3h). Isolated as yellow solid; yield: 88\%; 366 mg; mp: 206-208 ${ }^{\circ} \mathrm{C}$; IR ( $\left.\mathrm{KBr}, \mathrm{cm}^{-1}\right)$ : 3206, 3053, 2932, 2854, 1635, 1560, 1490, 1361, 1279, 1168, 1070, $775 \mathrm{~cm}^{-1} ;{ }^{1} \mathrm{H}$ NMR (400 MHz, DMSO- $\left.d_{6}\right) \delta 2.59(\mathrm{~s}, 3 \mathrm{H}), 3.10(\mathrm{~s}, 3 \mathrm{H}), 3.46(\mathrm{~s}$, $3 \mathrm{H}), 5.95(\mathrm{~s}, 1 \mathrm{H}), 7.13(\mathrm{~d}, J=8 \mathrm{~Hz}, 1 \mathrm{H}), 7.28-7.32(\mathrm{~m}, 2 \mathrm{H}), 7.48$ $(\mathrm{d}, J=8 \mathrm{~Hz}, 1 \mathrm{H}), 10.10(\mathrm{~s}, 1 \mathrm{H}),{ }^{13} \mathrm{C}$ NMR (100 MHz, DMSO- $\left.d_{6}\right)$ $\delta$ 16.7, 32.4, 40.9, 43.4, 112.8, 122.4, 126.1, 130.2, 131.0, 131.7, 136.7, 142.9, 156.4, 156.6; anal. calcd (\%) for $\mathrm{C}_{14} \mathrm{H}_{15} \mathrm{BrN}_{4} \mathrm{O}_{4} \mathrm{~S}: \mathrm{C}$, 40.49; H, 3.64; N, 13.49; S, 7.72. Found: C, 40.38; H, 3.66; N, 13.52; S, 7.75; anal. calcd for $\left[\mathrm{C}_{14} \mathrm{H}_{15} \mathrm{BrN}_{4} \mathrm{O}_{4} \mathrm{~S}+\mathrm{H}^{+}\right]$: calcd: 415.0070, found: 415.0070 .

4-(4-Fluorophenyl)- $N$,1-dimethyl-6-(methylthio)-3,5-dinitro1,4-dihydropyridin-2-amine (3i). Isolated as light yellow solid; yield: $90 \%$; $319 \mathrm{mg}$; mp: $230-232{ }^{\circ} \mathrm{C}$; IR $\left(\mathrm{KBr}, \mathrm{cm}^{-1}\right): 3216,3020$, 2958, 1620, 1562, 1480, 1395, 1277, 1180, 1074, $778 \mathrm{~cm}^{-1} ;{ }^{1} \mathrm{H}$ NMR (400 MHz, DMSO- $\left.d_{6}\right) \delta 2.60(\mathrm{~s}, 3 \mathrm{H}), 3.11(\mathrm{~d}, J=4.8 \mathrm{~Hz}, 3 \mathrm{H})$, $3.48(\mathrm{~s}, 3 \mathrm{H}), 6.08(\mathrm{~s}, 1 \mathrm{H}), 7.45(\mathrm{~d}, J=8.8 \mathrm{~Hz}, 2 \mathrm{H}), 8.17(\mathrm{~d}, J=$ $8.8 \mathrm{~Hz}, 2 \mathrm{H}), 10.15(\mathrm{~s}, 1 \mathrm{H}),{ }^{13} \mathrm{C}$ NMR $\left(100 \mathrm{MHz}, \mathrm{DMSO}-d_{6}\right) \delta 16.8$, 32.5, 41.1, 43.6, 112.5, 124.6, 128.8, 136.1, 147.3, 147.5, 156.4, 157.4; anal. calcd (\%) for $\mathrm{C}_{14} \mathrm{H}_{15} \mathrm{FN}_{4} \mathrm{O}_{4} \mathrm{~S}: \mathrm{C}, 47.45 ; \mathrm{H}, 4.27 ; \mathrm{N}$, 15.81, S, 9.05. Found: C, 47.35; H, 4.25; N, 15.78, S, 9.02.

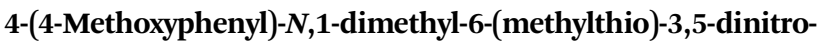
1,4-dihydropyridin-2-amine (3j). Isolated as yellow solid; yield: 92\%; $338 \mathrm{mg}$; mp: $200-202{ }^{\circ} \mathrm{C}$; IR ( $\left.\mathrm{KBr}, \mathrm{cm}^{-1}\right)$ : 3208, 3012, 2924, 2832, 1620, 1564, 1482, 1377, 1267, 1160, 1065, $710 \mathrm{~cm}^{-1} ;{ }^{1} \mathrm{H}$ NMR (400 MHz, DMSO- $\left.d_{6}\right) \delta 2.57$ (s, 3H), $3.10(\mathrm{~s}, 3 \mathrm{H}), 3.45$ (s, $3 \mathrm{H}), 3.71(\mathrm{~s}, 3 \mathrm{H}), 5.91(\mathrm{~s}, 1 \mathrm{H}), 6.86(\mathrm{~d}, J=8.8 \mathrm{~Hz}, 2 \mathrm{H}), 7.06(\mathrm{~d}, J=$ $8.8 \mathrm{~Hz}, 2 \mathrm{H}), 10.11(\mathrm{~s}, 1 \mathrm{H}),{ }^{13} \mathrm{C}$ NMR $\left(100 \mathrm{MHz}, \mathrm{DMSO}-d_{6}\right) \delta 16.5$, 32.3, 40.6, 43.3, 55.5, 113.5, 114.7, 128.4, 132.2, 138.1, 155.0, 156.5, 159.1; anal. calcd (\%) for $\mathrm{C}_{15} \mathrm{H}_{18} \mathrm{~N}_{4} \mathrm{O}_{5} \mathrm{~S}: \mathrm{C}, 49.17 ; \mathrm{H}$, 4.95; N, 15.29; S, 8.75. Found: C, 49.05; H, 4.93; N, 15.25; S, 8.72.

4-(3-Methoxyphenyl)- $N$,1-dimethyl-6-(methylthio)-3,5-dinitro1,4-dihydropyridin-2-amine (3k). Isolated as yellow solid; yield: 88\%; $323 \mathrm{mg}$; mp: $236-238{ }^{\circ} \mathrm{C}$; IR ( $\left.\mathrm{KBr}, \mathrm{cm}^{-1}\right): 3237,3015,2940$, 2837, 1618, 1562, 1489, 1358, 1285, 1174, 1072, $739 \mathrm{~cm}^{-1} ;{ }^{1} \mathrm{H}$ NMR (400 MHz, DMSO-d $\left.d_{6}\right) \delta 2.58(\mathrm{~s}, 3 \mathrm{H}), 3.10(\mathrm{~s}, 3 \mathrm{H}), 3.45(\mathrm{~s}$, $3 \mathrm{H}), 3.72(\mathrm{~s}, 3 \mathrm{H}), 5.97(\mathrm{~s}, 1 \mathrm{H}), 6.64(\mathrm{~s}, 1 \mathrm{H}), 6.70(\mathrm{~d}, J=8 \mathrm{~Hz}, 1 \mathrm{H})$, 6.84 (dd, $J=8 \mathrm{~Hz}, 3.2 \mathrm{~Hz}, 1 \mathrm{H}$ ), 7.24 (t, $J=8 \mathrm{~Hz}, 1 \mathrm{H}), 10.10$ (s, $1 \mathrm{H}),{ }^{13} \mathrm{C}$ NMR $\left(100 \mathrm{MHz}, \mathrm{DMSO}-d_{6}\right) \delta 16.6,32.4,40.6,43.3,55.5$, 113.0, 113.2, 119.2, 130.6, 137.6, 141.9, 155.4, 156.5, 159.9; anal. calcd (\%) for $\mathrm{C}_{15} \mathrm{H}_{18} \mathrm{~N}_{4} \mathrm{O}_{5} \mathrm{~S}: \mathrm{C}, 49.17 ; \mathrm{H}, 4.95 ; \mathrm{N}, 15.29 ; \mathrm{S}, 8.75$. Found: C, 49.08; H, 4.97; N, 15.32; S, 8.77; anal. calcd for $\left[\mathrm{C}_{15} \mathrm{H}_{18} \mathrm{~N}_{4} \mathrm{O}_{5} \mathrm{~S}+\mathrm{H}^{+}\right]$: calcd: 367.1070 , found: 365.1278 .

4-(3,4-Dimethoxyphenyl)- $N$,1-dimethyl-6-(methylthio)-3,5dinitro-1,4-dihydropyridin-2-amine (31). Isolated as yellow solid; yield: $90 \%$; $357 \mathrm{mg}$; mp: $242-244^{\circ} \mathrm{C}$; IR ( $\left.\mathrm{KBr}, \mathrm{cm}^{-1}\right): 3238$, 3002, 2842, 2930, 1618, 1563, 1470, 1361, 1234, 1162, 1074, $775 \mathrm{~cm}^{-1} ;{ }^{1} \mathrm{H}$ NMR (400 MHz, DMSO- $\left.d_{6}\right) \delta 2.57(\mathrm{~s}, 3 \mathrm{H}), 3.09(\mathrm{~d}, J$ $=4.4 \mathrm{~Hz}, 3 \mathrm{H}), 3.47(\mathrm{~s}, 3 \mathrm{H}), 3.69(\mathrm{~s}, 3 \mathrm{H}), 3.70(\mathrm{~s}, 3 \mathrm{H}), 5.91(\mathrm{~s}, 1 \mathrm{H})$, 6.62-6.66 (m, 2H), $6.87(\mathrm{~d}, J=6.6 \mathrm{~Hz}, 1 \mathrm{H}), 10.13(\mathrm{~s}, 1 \mathrm{H}),{ }^{13} \mathrm{C}$ NMR (100 MHz, DMSO- $\left.d_{6}\right) \delta 16.1,31.9,40.1,42.9,55.3,55.5$, 110.1, 111.9, 118.9, 132.1, 137.5, 148.2, 148.9, 154.7, 156.0; anal. calcd (\%) for $\mathrm{C}_{16} \mathrm{H}_{20} \mathrm{~N}_{4} \mathrm{O}_{6} \mathrm{~S}: \mathrm{C}, 48.48 ; \mathrm{H}, 5.09 ; \mathrm{N}, 14.13$, S, 8.09; found: $\mathrm{C}, 48.38 ; \mathrm{H}, 5.07 ; \mathrm{N}, 14.09, \mathrm{~S}, 8.06$; anal. calcd. for $\left[\mathrm{C}_{16} \mathrm{H}_{20} \mathrm{~N}_{4} \mathrm{O}_{6} \mathrm{~S}+\mathrm{H}^{+}\right]$: calcd: 397.1176 , found: 397.1176 .

\section{N,1-Dimethyl-6-(methylthio)-3,5-dinitro-4-(3,4,5-trimethoxyphenyl)-} 1,4-dihydropyridin-2-amine (3m). Isolated as yellow solid; yield: 92\%; 393 mg; mp: 260-262 ${ }^{\circ} \mathrm{C}$; IR (KBr, $\left.\mathrm{cm}^{-1}\right)$ : 3237, 2995, 2938, 2839, 1636, 1562, 1492, 1367, 1277, 1162, 1068, $719 \mathrm{~cm}^{-1} ;{ }^{1} \mathrm{H}$ NMR (400 MHz, DMSO- $\left.d_{6}\right) \delta 2.58(\mathrm{~s}, 3 \mathrm{H}), 3.11(\mathrm{~s}, 3 \mathrm{H}), 3.52(\mathrm{~s}$, $3 \mathrm{H}), 3.62(\mathrm{~s}, 3 \mathrm{H}), 3.74(\mathrm{~s}, 6 \mathrm{H}), 5.94(\mathrm{~s}, 1 \mathrm{H}), 6.37(\mathrm{~s}, 2 \mathrm{H}), 10.12(\mathrm{~s}$, $1 \mathrm{H}),{ }^{13} \mathrm{C}$ NMR (100 MHz, DMSO- $\left.d_{6}\right) \delta 16.6,32.3,41.2,43.4,56.3$, $60.40,104.3$, 113.2, 128.2, 135.9, 137.4, 137.6, 153.5, 155.4, 156.5; anal. calcd (\%) for $\mathrm{C}_{17} \mathrm{H}_{22} \mathrm{~N}_{4} \mathrm{O}_{7} \mathrm{~S}: \mathrm{C}, 47.88 ; \mathrm{H}, 5.20 ; \mathrm{N}$, 13.14; S, 7.52; found: C, 47.76; H, 5.17; N, 13.10; S, 7.49.

$N, 1-D i m e t h y l-6-(m e t h y l t h i o)-3,5-d i n i t r o-4-(p$-tolyl)-1,4dihydropyridin-2-amine (3n). Isolated as light yellow solid; yield: $94 \%$; $330 \mathrm{mg}$; mp: $212-214{ }^{\circ} \mathrm{C}$; IR $\left(\mathrm{KBr}, \mathrm{cm}^{-1}\right): 3163,3013$, 2954, 2854, 1628, 1564, 1488, 1390, 1270, 1186, 1077, $787 \mathrm{~cm}^{-1}$; ${ }^{1} \mathrm{H}$ NMR (400 MHz, DMSO- $\left.d_{6}\right) \delta 2.25$ (s, 3H), 2.57 (s, 3H), 3.09 (d, $J=5.2 \mathrm{~Hz}, 3 \mathrm{H}), 3.44(\mathrm{~s}, 3 \mathrm{H}), 5.95(\mathrm{~s}, 1 \mathrm{H}), 7.02(\mathrm{~d}, J=8 \mathrm{~Hz}, 2 \mathrm{H})$, 7.12 (d, $J=8 \mathrm{~Hz}, 2 \mathrm{H}), 10.11(\mathrm{~s}, 1 \mathrm{H}),{ }^{13} \mathrm{C}$ NMR (100 MHz, DMSO$\left.d_{6}\right) \delta 16.5,21.0,32.3,40.8,43.3,113.3,127.0,129.9,137.2,137.4$, 137.9, 155.2, 156.5 anal. calcd (\%) for $\mathrm{C}_{15} \mathrm{H}_{18} \mathrm{~N}_{4} \mathrm{O}_{4} \mathrm{~S}: \mathrm{C}, 51.42 ; \mathrm{H}$, 5.18; N, 15.99, S, 9.15. Found: C, 51.30; H, 5.16; N, 15.95, S, 9.12.

4-(4-Ethylphenyl)-N,1-dimethyl-6-(methylthio)-3,5-dinitro-1,4dihydropyridin-2-amine (3o). Isolated as light yellow solid; yield: 92\%; 336 mg; mp: $236-238{ }^{\circ} \mathrm{C}$; IR $\left(\mathrm{KBr}, \mathrm{cm}^{-1}\right): 3230,3010,2928$, 2856, 1623, 1564, 1480, 1395, 1278, 1180, 1076, $787 \mathrm{~cm}^{-1} ;{ }^{1} \mathrm{H}$ NMR (400 MHz, DMSO- $\left.d_{6}\right) \delta 1.13(\mathrm{t}, J=8 \mathrm{~Hz}, 3 \mathrm{H}), 2.53(\mathrm{q}, J=$ $7.6 \mathrm{~Hz}, 2 \mathrm{H}), 2.57$ (s, 3H), 3.09 (d, $J=5.2 \mathrm{~Hz}, 3 \mathrm{H}), 3.45(\mathrm{~s}, 3 \mathrm{H})$, $5.95(\mathrm{~s}, 1 \mathrm{H}), 7.05$ (d, $J=8 \mathrm{~Hz}, 2 \mathrm{H}), 7.15(\mathrm{~d}, J=8 \mathrm{~Hz}, 2 \mathrm{H}), 10.11$ (s, $1 \mathrm{H}),{ }^{13} \mathrm{C}$ NMR $\left(100 \mathrm{MHz}, \mathrm{DMSO}-d_{6}\right) \delta 15.9,16.5,28.2,32.3,40.7$, 43.3, 112.4, 127.2, 128.7, 137.6, 137.9, 143.5, 155.2, 156.5; anal. calcd (\%) for $\mathrm{C}_{16} \mathrm{H}_{20} \mathrm{~N}_{4} \mathrm{O}_{4} \mathrm{~S}: \mathrm{C}, 52.73 ; \mathrm{H}, 5.53 ; \mathrm{N}, 15.37, \mathrm{~S}, 8.80$. Found: C, 52.60; H, 5.51; N, 15.33, S, 8.77.

N,1-Dimethyl-6-(methylthio)-3,5-dinitro-4-(thiophen-2-yl)-1,4dihydropyridin-2-amine (3p). Isolated as light yellow solid; yield: 86\%; $295 \mathrm{mg}$; mp: $208-210^{\circ} \mathrm{C}$; IR $\left(\mathrm{KBr}, \mathrm{cm}^{-1}\right): 3103,3011,2928$, 1633, 1564, 1489, 1395, 1276, 1187, 1070, $778 \mathrm{~cm}^{-1} ;{ }^{1} \mathrm{H}$ NMR (400 MHz, DMSO- $d_{6}$ ) $\delta 2.52(\mathrm{~s}, 3 \mathrm{H}), 3.19(\mathrm{~s}, 3 \mathrm{H}), 3.45$ (s, 3H), 6.39 $(\mathrm{s}, 1 \mathrm{H}), 6.92(\mathrm{~d}, J=16 \mathrm{~Hz}, 2 \mathrm{H}), 7.42(\mathrm{~s}, 1 \mathrm{H}), 9.98(\mathrm{~s}, 1 \mathrm{H}),{ }^{13} \mathrm{C} \mathrm{NMR}$ (100 MHz, DMSO- $d_{6}$ ) $\delta 16.3$, 31.6, 36.4, 42.6, 124.3, 124.9, 127.2, 137.7, 142.7, 152.8, 155.8; anal. calcd (\%) for $\mathrm{C}_{12} \mathrm{H}_{14} \mathrm{~N}_{4} \mathrm{O}_{4} \mathrm{~S}_{2}: \mathrm{C}$, 42.09; H, 4.12; N, 16.36, S, 18.73. Found: C, 42.19; H, 4.14; N, 16.33, S, 18.70.

\section{Conflicts of interest}

There are no conflicts to declare.

\section{Acknowledgements}

Saigal and SK acknowledge the CSIR and UGC, New Delhi respectively, for their Fellowship. S. C. Sahoo acknowledge to DST-FIST for single crystal XRD facility. The authors are also thankful to IIT Patna, NCL Pune for providing NMR and HRMS facility. The authors are also grateful to the Chairman, Department of Chemistry, AMU, Aligarh, for providing necessary research facilities to complete this work. We are also thankful to the referees for their valuable suggestions. 


\section{Notes and references}

1 (a) R. A. Sheldon, Chem. Soc. Rev., 2012, 41, 1437-1451; (b) P. Gupta and S. Paul, Catal. Today, 2014, 236, 153-170; (c) R. C. Cioc, E. Ruijter and R. V. A. Orru, Green Chem., 2014, 16, 2958-2975; (d) C. de Graaff, E. Ruijter and R. V. A. Orru, Chem. Soc. Rev., 2012, 41, 3969-4009.

2 (a) H. G. O. Alvim, D. L. J. Pinheiro, V. H. Carvalho-Silva, M. Fioramonte, F. C. Gozzo, W. A. da Silva, G. W. Amarante and B. A. D. Neto, J. Org. Chem., 2018, 83, 12143-12153; (b) L. Zeng, B. Huang, Y. Shen and S. Cui, Org. Lett., 2018, 20, 3460-3464; (c) B. H. Rotstein, S. Zaretsky, V. Rai and A. K. Yudin, Chem. Rev., 2014, 114, 8323-8359; (d) J. Zhu and H. Bienayme, Multicomponent reactions, Wiley-VCH, Weinheim, Germany, 1st edn, 2005.

3 (a) H. G. O. Alvim, J. R. Correa, J. A. F. Assumpcao, W. A. da Silva, M. O. Rodrigues, J. L. de Macedo, M. Fioramonte, F. C. Gozzo, C. C. Gatto and B. A. D. Neto, J. Org. Chem., 2018, 83, 4044-4053; (b) B. B. Toure and D. G. Hall, Chem. Rev., 2009, 109, 4439-4486; (c) D. J. Ramon and M. Yus, Angew. Chem., Int. Ed., 2005, 44, 1602-1634; (d) J.-P. Wan and Y. Liu, Curr. Org. Chem., 2011, 15, 2758-2773.

4 (a) A. K. Bagdi, S. Santra, K. Monir and A. Hajra, Chem. Commun., 2015, 51, 1555-1575; (b) A. C. Boukis, K. Reiter, M. Frolich, D. Hofheinz and M. A. R. Meier, Nat. Commun., 2018, 9, 1439-1449; (c) N. Parikh, S. R. Roy, K. Seth, A. Kumar and A. K. Chakraborti, Synthesis, 2016, 48, 547-556.

5 (a) M. M. Khan, R. Yousuf, S. Khan and Shafiullah, RSC Adv., 2015, 5, 57883-57905; (b) L. F. Titze and A. Modi, Med. Res. Rev., 2000, 20, 304-322; (c) I. Ugi, A. Dömling and B. Werner, J. Heterocycl. Chem., 2000, 37, 647-658; (d) P. A. Tempest, Curr. Opin. Drug Discovery Dev., 2005, 8, 776-788; (e) H. Bienayme, C. Hulme, G. Oddon and P. Schmitt, Chem.-Eur. J., 2000, 6, 3321-3329.

6 (a) M. M. Khan, S. Khan, Saigal and S. Iqbal, RSC Adv., 2016, 6, 42045-42061; (b) J. P. Wan, L. Gan and Y. T. Liu, Org. Biomol. Chem., 2017, 15, 9031-9043; (c) Y. L. Gu, Green Chem., 2012, 14, 2091-2128.

7 (a) C. Villa, M. T. Genta, A. Bargagna, E. Mariani and A. Loupy, Green Chem., 2001, 3, 196-200; (b) S. Paul, M. Gupta, R. Gupta and A. Loupy, Tetrahedron Lett., 2001, 42, 3827-3829; (c) M. B. Gawande, S. N. Shelke, R. Zboril and R. S. Varma, Acc. Chem. Res., 2014, 47, 1338-1348; (d) A. Sarkar, S. Santra, S. K. Kundu, A. Hajra, G. V. Zyryanov, O. N. Chupakhin, V. N. Charushin and A. Majee, Green Chem., 2016, 18, 4475-4525; (e) A. Vass, J. Dudas, J. Toth and R. S. Varma, Tetrahedron Lett., 2001, 42, 5347-5349; (f) S. Roshandel, S. C. Suri, J. C. Marcischak, G. Rasul and G. K. S. Prakash, Green Chem., 2018, 20, 3700-3704.

8 (a) A. Pröbstle, A. Neszmelyi, G. Jerkovich, H. Wagner and R. Bauer, Nat. Prod. Lett., 2006, 4, 235-240; (b) A. Hantzsch, Chem. Ber., 1881, 14, 1637-1638.

9 D. J. Triggle, D. D. Langs and R. A. Janis, Med. Res. Rev., 1989, 9, 123-180.

10 M. Kawase, A. Shah, H. Gaveriya, N. Motohashi, H. Sakagami and A. J. Varga, Bioorg. Med. Chem., 2002, 10, 1051-1055.
11 (a) R. P. Mason, I. T. Mak, M. W. Trumbore and P. E. Mason, Am. J. Cardiol., 1999, 84, 16-22; (b) O. Aruoma, C. Smith, R. Cecchini, P. Evans and B. Halliwell, Biochem. Pharmacol., 1991, 42, 735-743.

12 A. Hilgeroth, Mini-Rev. Med. Chem., 2002, 2, 235-245.

13 C. Safak and R. Simsek, Mini-Rev. Med. Chem., 2006, 6, 747755.

14 S. Bahekar and D. Shinde, Acta Pharm., 2002, 52, 281-287.

15 S. Gullapalli and P. Ramarao, Neuropharmacology, 2002, 42, 467-475.

16 (a) R. Shan, C. Velaskez and E. E. Knaus, J. Med. Chem., 2004, 47, 254-261; (b) D. J. Triggle and D. Rampe, Trends Pharmacol. Sci., 1989, 10, 507-511; (c) H. Bocker and F. P. Guengerich, J. Med. Chem., 1986, 29, 1596-1603; (d) A. Sausins and G. Duburs, Heterocycles, 1988, 27, 269-289.

17 (a) X. Zhou, R. Coburn and M. Morris, J. Pharm. Sci., 2005, 94, 2256-2265; (b) X. F. Zhou, L. Zhang, E. Tseng, E. S. Ramsay, J. J. Schentag, R. A. Coburn and M. E. Morris, Drug Metab. Dispos., 2005, 33, 32132-321328; (c) K. Pajuste, Z. Hyvonen, O. Petrichenko, D. Kaldre, M. Rucins, B. Cekavicus, V. Ose, B. Skrivele, M. Gosteva, E. M. Picardat, M. Plotniece, A. Sobolev, G. Duburs, M. Ruponen and A. Plotniece, New J. Chem., 2013, 37, 3062-3075.

18 (a) E. Fasani, M. Fagnoni, D. Dondi and A. Albini, J. Org. Chem., 2006, 71, 2037-2045; (b) I. O. Donkor, X. Zhou, J. Schmidt, K. C. Agrawal and V. Kishore, Bioorg. Med. Chem., 1998, 6, 563-568; (c) T. Straub, C. Boesenberg, V. Gekeler and F. Boege, Biochemistry, 1997, 36, 1077710783; (d) A. Hilgeroth and H. Lilie, Eur. J. Med. Chem., 2003, 38, 495-499.

19 (a) G. Prasanthi, K. V. S. R. G. Prasad and K. Bharathi, Eur. J. Med. Chem., 2014, 73, 97-104; (b) V. P. Pandey, S. S. Bisht, M. Mishra, A. Kumar, M. I. Siddiqi, A. Verma, M. Mittal, S. A. Sane, S. Gupta and R. P. Tripathi, Eur. J. Med. Chem., 2010, 45, 2381-2388.

20 H. A. S. Abbas, W. A. El-Sayed and N. M. Fathi, Eur. J. Med. Chem., 2010, 45, 973-982.

21 (a) A. Hantzsch, Justus Liebigs Ann. Chem., 1882, 215, 1-82; (b) C. Simon, T. Constantieux and J. Rodriguez, Eur. J. Org. Chem., 2004, 24, 4957-4980; (c) P. Langer, Chem.-Eur. J., 2001, 7, 3858-3866.

22 (a) V. K. Sharma and S. K. Singh, RSC Adv., 2017, 7, 26822732; (b) J.-P. Wan and Y. Liu, RSC Adv., 2012, 2, 97639777; (c) J. Sun, Q. Wu, E.-Y. Xia and C.-G. Yan, Eur. J. Org. Chem., 2012, 35, 1976-1983; (d) L. Ohberg and J. Westman, Synlett, 2001, 8, 1296-1298; (e) D. Bandyopadhyay, S. Maldonado and B. K. Banik, Molecules, 2012, 17, 26432662.

23 (a) F. Rahimi, H. Hosseini, M. Bayat and Y. T. Jeong, Tetrahedron, 2018, 59, 818-822; (b) A. M. Jadhav, Y. I. Kim, K. T. Lim and Y. T. Jeong, Tetrahedron, 2018, 59, 554-557; (c) A. M. Jadhav, S. K. Krishnammagari, J. T. Kim and Y. T. Jeong, Tetrahedron, 2017, 73, 5163-5169; (d) M. V. Reddy, G. D. Reddy, J. T. Kim and Y. T. Jeong, Tetrahedron, 2016, 72, 6484-6491; (e) J. Mao, J. Wang, W. Zhang, Z. Li, J. Zhu and C. Guo, ARKIVOC, 2016, (iii), 171-186; $(f)$ B. Balachandra, S. Shanmugam, 
T. Muneewarahand and M. Ramakritinan, $R S C A d v ., 2015,5$, 64781-64789; (g) P. Gunasekaran, P. Prasanna and S. Perumal, Tetrahedron Lett., 2014, 55, 329-332; (h) N. Poomathi, J. Kamalraja, S. Mayakrishnan, D. Muralidharan and P. T. Perumal, Synlett, 2014, 25, 708712; (i) S. Sivakumar, R. R. Kumar, P. Elumalai, Q. N. Ahmed and A. K. Padala, ACS Comb. Sci., 2013, 15, 631-638; (j) K. Hajiyeva, A. Ismiev, M. Franz, M. Schmidtmann, J. Martens and A. Maharramov, Synth. Commun., 2017, 47, 1-5.

24 H. S. P. Rao and A. Parthiban, Org. Biomol. Chem., 2014, 12, 6223-6238.

25 M. M. Khan, Saigal, S. Shareef, S. Khan and S. C. Sahoo, Synth. Commun., 2018, 48, 2683-2694.

26 (a) M. M. Khan, Saigal, S. Khan, S. Shareef and M. Danish, ChemistrySelect, 2018, 3, 6830-6835; (b) M. M. Khan,
Saigal, S. Khan, S. Shareef and S. Hussain, ChemistrySelect, 2018, 3, 2261-2266; (c) M. M. Khan, S. Khan, Saigal and S. C. Sahoo, ChemistrySelect, 2018, 3, 1371-1380; (d) M. M. Khan, S. Khan, S. Iqbal, Saigal and R. Yousuf, New J. Chem., 2016, 40, 7504-7512.

27 Green metrics reviews, see: (a) F. Roschangar, R. A. Sheldon and C. H. Senanayake, Green Chem., 2015, 17, 752-768; (b) J. Augé, Green Chem., 2008, 10, 225-231; (c) C. JimenezGonzalez, C. S. Ponder, Q. B. Broxterman and J. B. Manley, Org. Process Res. Dev., 2011, 15, 912-917.

28 (a) X. Zhang, G. Dhawan, A. Muthengi, S. Liu, W. Wang, M. Legris and W. Zhang, Green Chem., 2017, 19, 38513855; (b) P. Wadhwa, T. Kaur and A. Sharma, RSC Adv., 2015, 5, 44353-44360.

29 C. Jiménez-González, D. J. C. Constable and C. S. Ponder, Chem. Soc. Rev., 2012, 41, 1485-1498. 